\title{
Comparative Analysis on Jogging Jacket Product for Urban Society (Case Study : Society of Bandung City)
}

\author{
Iqbal Ghiffari ${ }^{1}$, Muchlis ${ }^{2}$ \\ ${ }^{1}$ Desain Produk, Fakultas Industri kreatif, Bandung, Indonesia \\ 2 Desain Produk, Fakultas Industri Kreatif, Bandung, Indonesia
}

iqbal.ghiffari22@gmail.com (Iqbal Ghiffari),muchlis@dp.stisitelkom.ac.id (Muchlis)

\begin{abstract}
Jogging is one of the kind of sport that the urban societies loves in order to maintain their health. When doing jogging, urban people tend to need a variety of support items, these items are usually stored in a jacket pocket that they use when jogging. This way of storing creates discomfort while doing jogging, it is caused by the movement of items that stored inside the jacket pockets that they use when jogging, the items moving into opposite direction to the direction of body move-ment. To solve this discomfort problems, a research is done using descriptive qualitative research method which will be followed by data collecting technique through survey, field observation, interview and literature study, then data which have been obtained, will be analyzed using comparative method. The comparative method is implemented by comparing several jogging jacket products with different storing positions. Based on the results of the analysis, it is found that the characteristics of a jacket that appropriate for the urban society is a jacket that has a limited space of storage and the storage has to be place right next to the body so the movement of the goods will move into the same direction as the movement of the body, so the movement of the goods into the opposite direction with the body can be minimized.
\end{abstract}

Keywords : Jogging, Jacket, Items, Storage, Movements, Comforts.

\section{Introduction}

Jogging is a sport that is favored by the urban society, including the society of bandung city, jogging is also one of a kind healthy lifestyle that commonly done by the urban soci-eties. While doing this lifestyle, the urban society usually re-quires various supporting stuff like gadgets to accompany them along the activity.

When doing jogging, urban societies generally use the jacket as a storage for their stuffs that they bring with. This way of storing makes discomforts situation while doing jog-ging, this is caused by the movement of the goods stored in-side the pocket of the jacket that they use while jogging is moving into the opposite direction against the body motion direction, this condition causes any discomfort due the shocks and contacts from the stuffs against the body of the user of the jacket.

Looking through this problem, the author will analyze jog-ging jacket with various type of storage models through com-parisons of methods to discover the characteristics of the jacket that can minimize the shock of goods at the place of the pocket of a jacket which occur due to the movement of body while doing jogging.

\section{Theoritical Studies}

\subsection{Urban Society}

According to R. Wibowo (in Putri Amalia Sari 2013:21) which states that "the urban society is significantly close to the sophistication of the information technology because it supported by life facilities in urban areas. This is cer-tainly also will lead to different needs of supporting stuffs."

\subsection{Lifestyle}

According to Alfred Adler (in Siti Miftakhul Jannah Budi-harjo 2012:30), "lifestyle is a set of behaviors that have meaning for the individual or others at one time in one place, including in social relations, consumption goods, entertain-ment and clothing."

\subsection{Jogging}

According to Jonathan Kuntaraf (in Sugeng Purwanto 2012:3) argued that " jogging as running slowly and continuesly." While jogging exercise, according to Cooper's (in Sugeng Purwanto 2012:3) it is said that "If someone run 
faster than 9 seconds for a distance of $1.6 \mathrm{~km}$, then we refer it as running, but when the distance travelled slower than 9 minutes, then we call it jogging.

\subsection{Jogging Jacket}

As presented earlier, jogging a kind of running exer-cise, when running, the type of jacket that suitable is a jacket that has a good air circulation, it is aimed at helping evaporating sweat from the body when exercising. As pre-sented by Michael Spilling and Sean Fishpool ( 2012 : 18 )"Runners produce a lot of sweat, so a lightweight, breatheable jacket that lets perspiration escape is a comfortable option. A jacket that breathes well will not only be water-resistant, but will also be wind-resistant, which helps to stave of a chill. Most runners avoid fully waterproof jackets because they cause the body to become hot and sweaty. Technical fabrics such as Klimate keep water out but breathe so sweats evaporates."

\subsection{Jogging body gesture}

According to Yudha M. Saputra (20120 :98) Jogging has this following characteristic: "the gesture of the body has to be leaning slightly forward, the head should be upright and staring directly forward, movement of the feet when stepping does not have to be to long, just around $30-40 \mathrm{~cm}$ only, when landing the foot it has to be in the both end part of the foot, the foot position should be relaxed, arm swung reasonably with finger does not need to be clenched enough with slightly opening it, the rhythm of running mutually aligned between the hands and feet.

\subsection{Comforts}

According to Kolcaba (in Eva Violesia Bangun 2014:10) explained that 'comfort as a state of fullfilled basic human needs that are individualized and holistic. With fullfilled comfort condition, it cause a peaceful feeling inside the indi-vidual.'

\subsection{Ergonomic}

According to OSHA (in Hotmian Situmorang 2013: 7) "Ergonomics is a practice in designing tools and detailed work compatible with the capacity of workers in order to pre-vent injuries on workers."

\section{Research Method}

\subsection{Approach Method}

The approach method used in this research is descriptive qualitative approach, with this method, collected data will be decribed narratively.

\subsection{Data Collecting Method}

The data collecting method is done using respondent interview, survey, field observation dan literature study related to the problem. The survey is done by spreading questionnaire, and the observation is done in 2 ways, the one with participative observation and non participative observation.

\subsection{Analysis Method}

The method that is used to analyzed the data is compara-tive method, Comparative method according to Poer-wodanrminto (in Wiji Hastuti 2009:8) "the study comes from the English "to study" which means want to get or learn. Study means wants to get a special driven by curiosity to something that has not been studied and known. While the comparative comes from the English "to compare" which means comparing at least two problems and there are two factors of similarity and difference factors"

\section{Analysis and Result}

\subsection{Empiric Studies}

\subsubsection{Research Subject}

In this research, society of Bandung city becoming the subject of this research, this is because the society of Ban-dung city can represent the characteristics of urban society along with the lifestyle, the existence of jogging activity area in bandung city also become the reason for the selection of society of Bandung city as a research object. The city of Bandung has several sports jogging areas, named Sabuga sports area, Gasibu and Saparua Sports Arena.

\subsubsection{Questionnaire data collecting}

According to the data collected from the questionnaire, it is shown that:

1. A total of $77 \%$ of respondents claimed to carry goods while doing jogging.

2. If sorted into a priority scale, Mobile phones is ranked first with the largest percentage, then there are keys, wal-lets, drink bottles, music player, handsfree, towel and other personal items that support the needs of respond-ents while doing jogging. But all these needs are not nec-essarily brought together by the subject, only a portion of the item has been described and some important things according to the subjects.

3. Based on the results of the questionnaire, $30 \%$ of the re-spondents claimed choosing to store goods on the jacket pocket, this percentage is the largest compared to other storage percentage.

4. A total of $57 \%$ of respondents feel uncomfortable with their storage position.

\subsubsection{Observation data collecting}

1. Jogging Preparation

Preparations done by jogging before jogging include changing clothes, and preparing some things to support his jogging activities, because in some cases jogging joggers are not ready to jog. 
While observing the sports area of Sabuga, Gasibu and Saparua, it appears that when going to jog it looks that someone will prepare their various needs to jog first before jogging. The needs is none other than the music player integrated with mobilephone, Wallet, key

and so forth, generally the joggers putting down the goods inside the pants pocket or jacket pocket, Then continued by tightening the shoelaces and a few initial stretches before jogging.

\section{The Joggers}

The society of Bandung city who visited the jogging sports area in the city of Bandung has a fairly diverse age, but based on the observations, people who do jogging with carrying goods generally are in the range of adolescence and adulthood, it is proved by the results of the questionnaire that the age of 16 years to 26 years is a the most dominant age of joggers.

3. Doing jogging with goods

Based on the observation, when doing jogging, generally a person keeps the goods on the pocket of the jacket and pants pocket when doing jogging.

When storing goods and doing jogging at the same time, the body movements when doing jogging will leads to another movements in opposite directions on goods stored in storage around the body.

Based on the observations, it is founded that some things that pointed to affect the movement of goods while jogging, it is founded that the more significant movement of the body then the opposite movement of the goods will also be more significant, then the space of distance between storage and the body is making a momentum of goods to move contrary with the body.

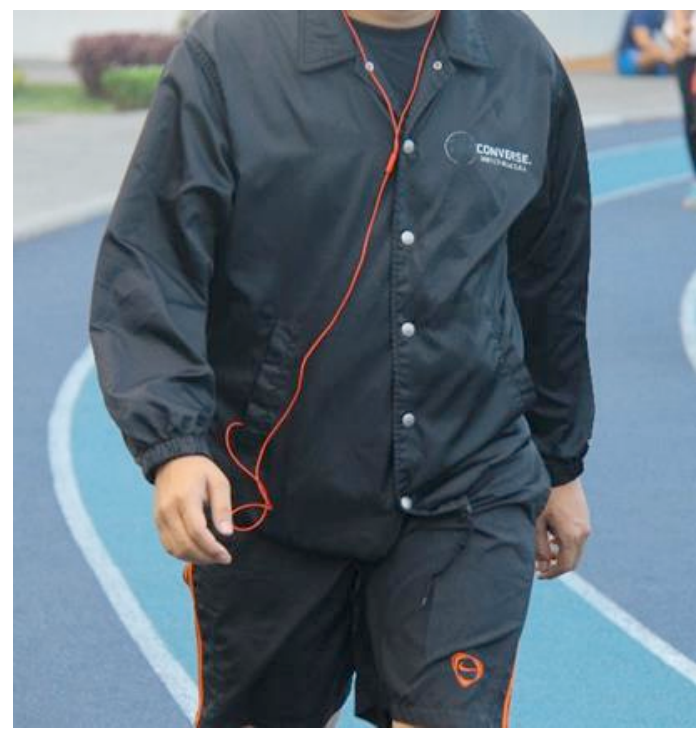

Figure 1. Storing goods inside a jacket while doing jogging
4. Drinking While jogging

When doing jogging, the joggers generally hold their drinking bottle on their hand when exercising. Based on the observation, it does not seem at all a person's habit to keep a bottle in a container when doing jogging.

\section{Jackets for Jogging}

Currently there are various types of jogging jackets with different storage positions, first of all, there is a jogging jacket with storage on the chest, commonly used to store 1 type of goods.

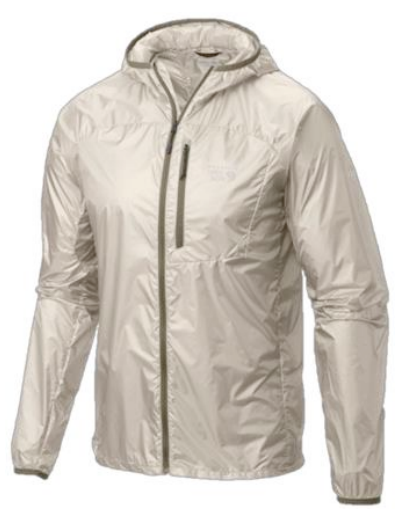

Figure 2. Chest positioned storage jacket.

Then there is the jacket with the storage position on the arm, due to its position which is on the tight part of the body, this storage location can only be used to store mobilephone and other small objects.

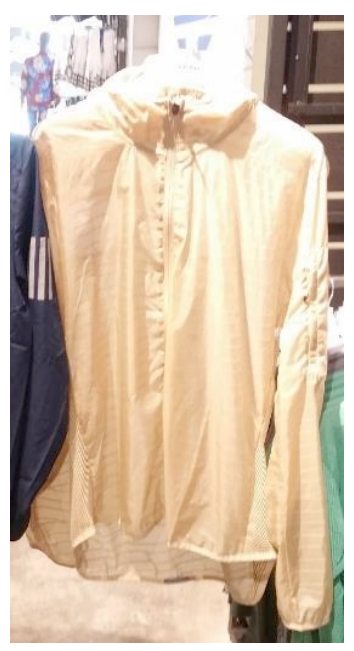

Figure 3. Arm positioned storage jacket.

And then a jacket with storage on the abdomen area, is the most common form of storage encountered. With the position located in the middle of the body, resulting in the two pockets can be accessed by both hands. This type of storage can be used to store mobile phones, wallets, keys and other small items. 


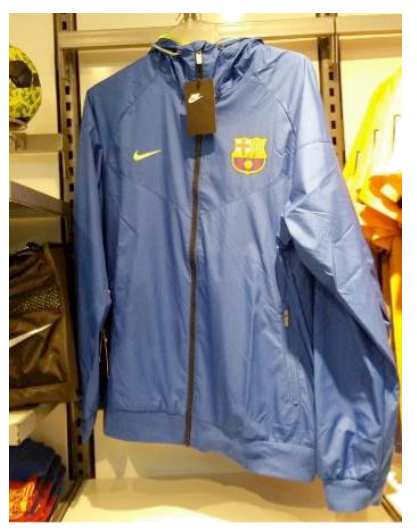

Figure 4. abdominal positioned storage jacket.

Then there is a jacket with no storage at all, so it can not be used to store any items. Or in other word, this kind of jacket is not designed to carry any goods.

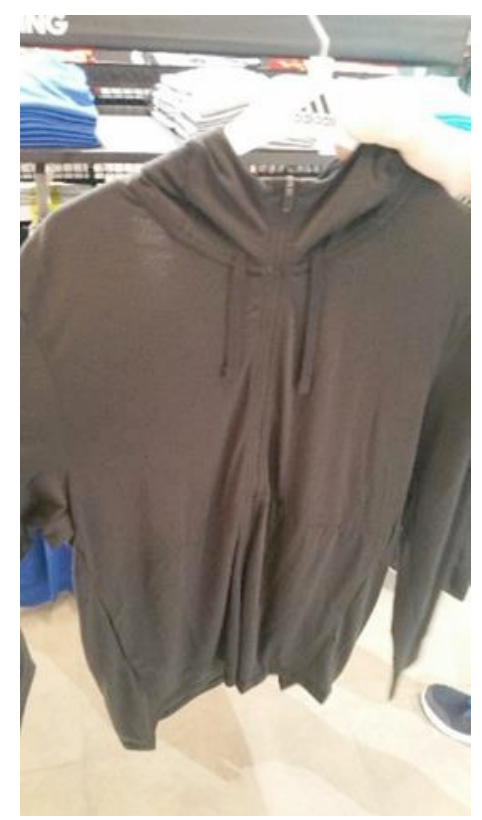

Figure 5. Jacket without storage.

6. Jacket pocket Dimension

To find the appropriate storage sizes, a suitable size study is to be used for storage of items that have a probability of being taken while jogging. Based on observations, it is found that the appropriate mobile storage is with a storage height of $15 \mathrm{~cm}$ and width of up to $8 \mathrm{~cm}$. Then the appropriate key store is with a storage height of $8.9 \mathrm{~cm}$ and width of up to $3.8 \mathrm{~cm}$. And the storage of this type of wallet has a size with a height of $8-9 \mathrm{~cm}$, width of up to $10 \mathrm{~cm}$ and up to $2 \mathrm{~cm}$ thick.

\subsubsection{Interview data collecting}

1. The comforts of doing jogging with goods

Based on interviews to the respondents about the convenience of jogging with storing goods on the jacket, after jogging for 30 minutes, the respondents concluded that there is discomfort caused by the movement of goods that occur when jogging, and in contact with the body resulting in discomfort. Movement of goods on the jacket is also caused by the type of jacket pocket that has a design that does not stick with the body so it has the momentum to move.

This discomfort produces a sense of freedom to move while jogging, as more movement of the body will result in greater movement of goods, which will also interfere with comfort.

\subsection{Data Analysis}

In order to create a solutive product, it is necessary to obtain a priority scale description of the aspects to be considered in the design product; these analyzes are not the design aspect analysis.

The following is a description of the problems of this study and the aspects related to the problem:

Table 1. Design aspect description

\begin{tabular}{|c|l|l|}
\hline No. & Research Problems & Design Aspect \\
\hline 1 & $\begin{array}{l}\text { Barang kebutuhan yang harus dipenuhi } \\
\text { ketika joging. } \\
\text { things that needed to fulflill when doing } \\
\text { jogging }\end{array}$ & Function \\
\hline 2 & $\begin{array}{l}\text { Fenomena seseorang yang umumnya } \\
\text { menyimpan barang ketika melakukan } \\
\text { joging. } \\
\text { The phenomenon of people bring and } \\
\text { storing things while jogging. }\end{array}$ & nomic \\
\hline 3 & $\begin{array}{l}\text { Barang yang bergerak mengenai tubuh, } \\
\text { akibat gerak tubuh ketika melakukan } \\
\text { joging. } \\
\text { The contact between the body and the } \\
\text { goods while doing jogging. }\end{array}$ & Ergonomic \\
\hline
\end{tabular}

Based on previous explanation, the analysis is done by comparative method, by comparing the existing jogging jacket that is focused on the storage place owned. Comparative analysis is done on two aspects, namely aspects of ergo-nomics and function.

\subsubsection{Ergonomic aspect comparative}

Table 2. Ergonomic aspect comparative analysis

\begin{tabular}{|c|c|c|c|}
\hline No & $\begin{array}{l}\text { Pocket } \\
\text { Positioning }\end{array}$ & Advantage & Disadvantage \\
\hline 1 & $\begin{array}{l}\text { Chest posi- } \\
\text { tioning }\end{array}$ & $\begin{array}{l}\text { - Can be reached } \\
\text { by both hands. } \\
\text { - This position } \\
\text { does not have sig- } \\
\text { nificant move- } \\
\text { ment while doing } \\
\text { jogging. } \\
\text { - The placement of } \\
\text { goods in a limited } \\
\text { space of storage }\end{array}$ & $\begin{array}{l}\text { - Keeping a lot of stuff } \\
\text { on the chest, can } \\
\text { cause discomfort } \\
\text { when breathing while } \\
\text { exercising. } \\
\text { - Small space storage } \\
\text { will be difficult to ac- } \\
\text { cess when it got tight } \\
\text { with the goods. }\end{array}$ \\
\hline
\end{tabular}


Table 2. cont

\begin{tabular}{|c|c|c|c|}
\hline & & $\begin{array}{l}\text { limits the goods } \\
\text { movement space }\end{array}$ & \\
\hline 2 & $\begin{array}{l}\text { Arm posi- } \\
\text { tioning }\end{array}$ & $\begin{array}{l}\text { - Despite of having } \\
\text { a significant } \\
\text { movement, arms } \\
\text { storage will not } \\
\text { causing an impact } \\
\text { between the goods } \\
\text { and the body. } \\
\text { - No internal or- } \\
\text { gans affected- } \\
\text { when storing } \\
\text { goods on this po- } \\
\text { sition while doing } \\
\text { sports. } \\
\text { - Placement posi- } \\
\text { tion on the tight } \\
\text { part of the jacket, } \\
\text { causing goods at- } \\
\text { tached to the } \\
\text { body and do not } \\
\text { experience a sig- } \\
\text { nificant move- } \\
\text { ment. } \\
\text { - The placement of } \\
\text { goods in a limited } \\
\text { space of storage } \\
\text { limits the goods } \\
\text { movement space. }\end{array}$ & $\begin{array}{l}\text { - Cannot be reached or } \\
\text { accessed by both } \\
\text { hands. } \\
\text { - The goods can still } \\
\text { move and rub against } \\
\text { the arm from inside } \\
\text { the storage. } \\
\text { - Small space storage } \\
\text { will be difficult to ac- } \\
\text { cess when it got tight } \\
\text { with the goods. }\end{array}$ \\
\hline 3 & $\begin{array}{l}\text { Abdominal } \\
\text { positioning }\end{array}$ & $\begin{array}{l}\text { - Centered place- } \\
\text { ment will not } \\
\text { making an unbal- } \\
\text { anced feeling } \\
\text { whenstoring } \\
\text { goods while do- } \\
\text { ing jogging } \\
\text { - Can be reached } \\
\text { by both hands. }\end{array}$ & $\begin{array}{l}\text {-The storage position is } \\
\text { located in an area of } \\
\text { body that has an oppo- } \\
\text { site movement, this } \\
\text { condition causing } \\
\text { goods movements in- } \\
\text { side the pocket as well, } \\
\text { as well as the placing } \\
\text { of goods right in front } \\
\text { of the movement of the } \\
\text { body. } \\
\text {-When jogging the body } \\
\text { will be slightly inclined } \\
\text { forward, so that will } \\
\text { create momentum } \\
\text { space to collide with } \\
\text { the body, the direction } \\
\text { of gestures. } \\
\text {-Large storage sizes lead } \\
\text { to the bigger space for } \\
\text { the goods to move. }\end{array}$ \\
\hline
\end{tabular}

Regarding the accessibility to storage, an anthropometry size of the Indonesian society is used to measure the metacarpal width required. The following picture is an anthropometry data of Indonesians and their dimensions by Nurmianto.

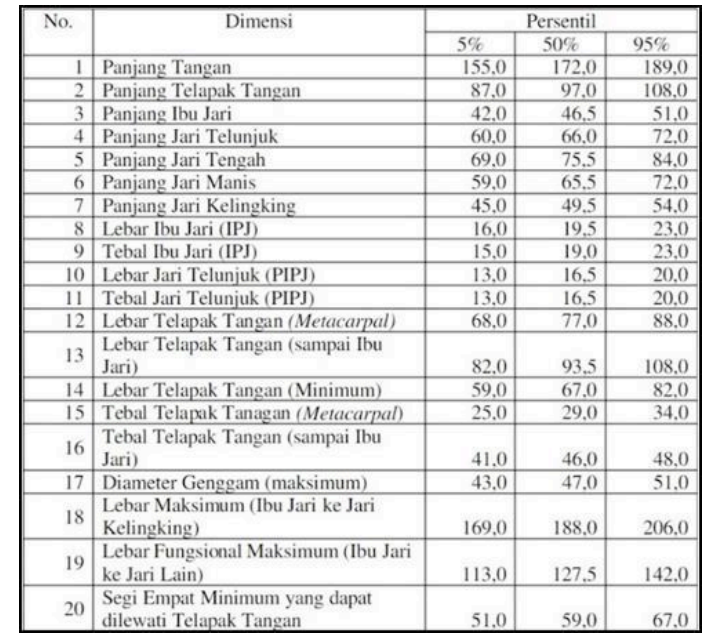

Figure 6. Nurmianto's Indonesian anthropometry data ( in Novita Cahyawati $2008: 4)$.

According to the anthropometry data above, by taking data on the 95th percentile calculation, it can be concluded that 10.8 Centimeters is the largest average metacarpal measure of Indonesian hands.

Based on the comparative analysis results that have been done earlier, known that :

1. The goods will not make an impact, if its not placed on a position of body movement direction that move signif-icantly when jogging.

2. The minimum access area size suitable for use is 10.8 $\mathrm{cm}$.

3. Storage on the tight side, can make it difficult for acces-sibility of goods.

4. Good position placement is a placement that does not disturb the work of the body while doing jogging.

5. The movement of goods can be minimized by the position of the laying that really touches the body, and the movement of movement in the limited storage.

\subsubsection{Function Aspect Comparative}

Table 3. Function aspect comparative analysis

\begin{tabular}{|c|c|c|c|}
\hline No & $\begin{array}{l}\text { Pocket } \\
\text { Positioning }\end{array}$ & Advantage & Disadvantage \\
\hline 1 & $\begin{array}{l}\text { Chest } \\
\text { positioning }\end{array}$ & $\begin{array}{l}\text { - The goods is eas- } \\
\text { ier to accessed, } \\
\text { because there's } \\
\text { only one goods } \\
\text { inside the pocket. }\end{array}$ & $\begin{array}{l}\text { - This position is not } \\
\text { suitable to store mul- } \\
\text { tiple goods, because } \\
\text { of its size. It only } \\
\text { suitable to store one } \\
\text { small goods. }\end{array}$ \\
\hline
\end{tabular}


Table 3. cont.

\begin{tabular}{|c|l|c|c|}
\hline 2 & $\begin{array}{l}\text { Arm } \\
\text { positioning }\end{array}$ & $\begin{array}{c}- \text { The goods is eas- } \\
\text { ier to accessed, } \\
\text { because there's } \\
\text { only one goods } \\
\text { inside the pocket. }\end{array}$ & $\begin{array}{c}\text { - This position is not } \\
\text { suitable to store mul- } \\
\text { tiple goods, because } \\
\text { of its size. It only } \\
\text { suitable to store one } \\
\text { small goods. }\end{array}$ \\
\hline 3 & Abdominal \\
positioning & $\begin{array}{c}\text { - Different storage } \\
\text { places minimize } \\
\text { the probability of } \\
\text { damaged goods in- } \\
\text { side the pocket due } \\
\text { to the movement } \\
\text { of the body. } \\
\text { - Big volume stor- } \\
\text { age, could be used } \\
\text { to store more than } \\
\text { one goods. }\end{array}$ & $\begin{array}{c}\text {-The goods will be } \\
\text { slightly more time- } \\
\text { consuming to access, } \\
\text { when the storage is } \\
\text { used to store multiple } \\
\text { goods inside one stor- } \\
\text { age. } \\
\text {-Due to its big volume } \\
\text { of storage, the proba- } \\
\text { bility of goods move- } \\
\text { ment inside the } \\
\text { pocket is bigger than } \\
\text { the other position } \\
\text { type. }\end{array}$ \\
\hline
\end{tabular}

Based on the analysis that has been done on the function aspect, known that :

1. Putting each goods in different storage can avoid contact between goods and stop the movement between goods.

2. Placement on goods in different storage will easier to ac-cessed.

3. Large storage areas do not guarantee comforts.

\subsection{Analysis Results}

\subsubsection{Design Considerations}

Based on the analysis explanation on design aspects that have been described earlier, there are some consideration that things that can be considered as consideration in product design, the considerations are:

1. The goods will not make an impact, if its not placed on a position of body movement direction that move signif-icantly when jogging.

2. The minimum access area size suitable for use is 10.8 $\mathrm{cm}$.

3. Storage on the tight side, can make it difficult for acces-sibility of goods.

4. Good position placement is a placement that does not disturb the work of the body while doing jogging

5. Putting each goods in different storage can avoid contact between goods and stop the movement between goods.
6. Placement on goods in different storage will easier to ac-cessed.

7. Large storage areas do not guarantee comforts.

\subsubsection{Design Constraints}

Based on previous exposure, the research will be limited by focusing the research on several things, these are:

1. Development focuses only on integrated shelters on jackets.

2. Research is focused on minimizing the issue of movement of luggage that concerns the body, when the body moves while jogging.

3. Storage space is limited to store only 3 items that have been determined.

\subsubsection{Design Requirements}

Based on the description of some aspects before there are some things that need in the design of the product, these needs among others are:

1. Products are required to minimize the movement of goods resulting in contact with the body when jogging.

2. The product requires a minimum access area of $10.8 \mathrm{~cm}$.

3. Storage with different places between several items, can avoid contact between luggage.

4. The method of storing the goods with the position of the laying that touches the body, and space in the restricted storage.

\section{Conclusion}

Based on comparative analysis of the issues raised about jogging jackets, to minimize the problem of goods movement that causes discomfort when jogging, a jacket requires the following characteristics:

1. The storage has to be placed in a body part that has no significant motion.

2. There have to be no distance between the body and the storage, because by putting the storage touching the body of the user, the goods will moving into the same irection as the direction of the user body.

3. The size of the storage has to be in accordance with the dimensions of goods entered, this also serves to minimize the movement of goods with limiting the space of the storage.

4. The position of storage should not blocking the movement of the body when jogging, because this will cause discomfort that comes from the disruption of body movement. 
With the characteristics that have been described above, carrying goods while doing jogging innate can be comfortable when the goods stored in a jacket with the characteristics mentioned above.

\section{REFERENCES}

[1] Purwanto, Sugeng. 2012. Perbedaan Pengaruh Antara Latihan Joging dan jalan Jalan Cepat Terhadap Tingkat Kesegaran Jasmani. Yogyakarta : Jurnal Indonesian Sport Scientist As-sociation.(http://staffnew.uny.ac.id/upload/132315279/penelitian/PERBE-

DAAN+PENGARUH.pdf)

[2] Bangun, Eva Violesia. 2014. Pengaruh Warna Ruang Kerja Terhadap Kenyamanan Dosen Departemen Psikologi Industri dan Organisasi. Journal : Medan. Universirtas Sumatera Utara. (http://repository.usu.ac.id/bitstream/handle/123456789/41143/Chapter\%20II.pdf?sequence=4\&isAllowed $=\mathrm{y}$ )

[3] Situmorang, Hotmian A. M. 2013. Gambaran Keluhan Musk-uloskeletal pada Pekerja Pembuat Tas di Jalan Bajak V Keca-matan Medan Amplas. Journal : Medan. Universitas Su-matera Utara. (http://repository.usu.ac.id/bitstream/handle/123456789/41143/Chapter\%20I.pdf?sequence $=4 \&$ isAllowed $=\mathrm{y}$ )

[4] Budiharjo, Siti Miftakhul Jannah. 2012 Kajian Keterkaitan Gaya Hidup Mahasiswa Dengan Tata Ruang Koridor Jalan Babasari Yogyakarta. Thesis : Yogyakarta. Universitas Atma Jaya Yogyakarta. (http://e-journal.uajy.ac.id/433/3/2MTA01486.pdf)

[5] Sari, Putri Amalia. 2013. Kebiasaan Nongkrong Remaja Masa Kini di Mall Royal Plaza Surabaya. Skripsi : Surabaya. Institut Agama Islam Sunan Ampel Surabaya. (http://digilib.uinsby.ac.id/11028/4/bab\%202.pdf)

[6] Hastuti, Wiji. 2009. Studi Komparasi penggunaan metode STAD (Student Team Achievment Divission) dilengkapi modul dengan LKS terhadap Prestasi Belajar siswa sub Pokok Bahasan Konsep mol semester I SMA Negeri 1 Manyaran Ta-hun Ajaran 2008/2009. Surakarta : Universitas Sebelas Maret.(https://eprints.uns.ac.id/188/1/167260309201011431. pdf)
[7] Saputra, Yudha M. 2004.Dasar-Dasar Keterampilan Atletik. Jakarta : Direktorat Jendral Olahraga (http://file.upi.edu/Direktori/DUAL-MODES/PENJASKES/BBM_1.pdf)

[8] Cahyawati, Novita (2008) Perancangan Fasilitas Fisik, Lingkungan Fisik, dan Tata Letak Fasilitas Fisik Dalam Kabin Yacht Ditinjau Dari Segi Ergonomi. (http://repository.maranatha.edu/4741/2/0423073_Appendices.pdf) 